\title{
Synthesis, spectral and thermal study of La(III), Nd(III), Sm(III), Eu(III), Gd(III) and Tb(III) complexes with mefenamic acid
}

\author{
Lidia Zapała ${ }^{1}$ - Małgorzata Kosińska ${ }^{1} \cdot$ Elżbieta Woźnicka $^{1} \cdot$ Lukasz Byczyński $^{2}$. \\ Wojciech Zapała ${ }^{3}$
}

Received: 10 July 2015/Accepted: 21 October 2015/Published online: 4 November 2015

(c) The Author(s) 2015. This article is published with open access at Springerlink.com

\begin{abstract}
New binuclear complexes of $\mathrm{La}(\mathrm{III}), \mathrm{Nd}(\mathrm{III})$, $\mathrm{Sm}(\mathrm{III}), \mathrm{Eu}(\mathrm{III}), \mathrm{Gd}(\mathrm{III})$ and $\mathrm{Tb}(\mathrm{III})$ ions with mefenamic acid were obtained in solid phase. For all compounds considered, complexation occurs at $\mathrm{pH}$ 6-6.5. The analyzed complexes were characterized on the basis of chemical and elemental analyses, molar conductance, UVVis, IR and 1H NMR spectroscopies as well as thermoanalytical techniques. According to the research results, the molecular formula of the complexes is $\mathrm{Ln}_{2}\left(\mathrm{C}_{15} \mathrm{H}_{14}\right.$ $\left.\mathrm{NO}_{2}\right)_{3}(\mathrm{OH})_{3} \times \mathrm{nH}_{2} \mathrm{O}$, with the exception of the $\mathrm{La}(\mathrm{III})$ complex which has the formula $\mathrm{La}_{2}\left(\mathrm{C}_{15} \mathrm{H}_{14} \mathrm{NO}_{2}\right)_{5}(\mathrm{OH})$. The results show that only the carboxyl group is involved in the coordination of the rare earth ions in the bidentate mode. Coordination does not occur through the nitrogen atom. All the complexes are soluble in DMSO, and they are nonelectrolytes. The TG-FTIR technique was employed in order to study a decomposition pathway of the obtained compounds. The received results provide information on the composition, thermal stability, thermal decomposition, as well as the gaseous products that evolved during the thermal decomposition of the considered compounds.
\end{abstract}

Lidia Zapała

lzapala@prz.edu.pl

1 Department of Inorganic and Analytical Chemistry, Faculty of Chemistry, Rzeszów University of Technology, Al. Powstańców Warszawy 6, 35-959 Rzeszow, Poland

2 Department of Polymer Technology, Faculty of Chemistry, Rzeszów University of Technology, Al. Powstańców Warszawy 6, 35-959 Rzeszow, Poland

3 Department of Chemical and Process Engineering, Faculty of Chemistry, Rzeszów University of Technology, Al. Powstańców Warszawy 6, 35-959 Rzeszow, Poland
Keywords Mefenamic acid - Lanthanide complexes · Spectral studies - Thermal analysis · TG-FTIR

\section{Introduction}

Lanthanides present specific chemical, optical and magnetic properties that are a consequence of their peculiar electronic structure. Furthermore, when used in small quantities, they become essential to almost all aspects of modern life, from functioning as the active cores in catalysts for oil cracking, lighting devices, high-coercivity magnets used in motorization (electric cars, wind turbines, hard disk drives) or audio applications, lasers and telecommunications, to different areas as biomedical analyses and imaging or agriculture [1].

Many studies concerning the lanthanides and their interactions with biological systems are currently carried out in order to gain a better understanding of their functional roles in biology and medicine. Lanthanides have been suggested for the treatment of a series of diseases and for diagnosis through magnetic resonance imaging [2]. Recent studies have shown that lanthanides could act as scavengers of free radicals and therefore protect cells and tissues from oxidative stress-induced injury [3]. A coordination compound of rare earth and drug may exhibit higher biological activity than that of metal or ligand because of synergetic effects $[4,5]$.

Mefenamic acid (2-[N-(2,3-dimethylphenyl)amino]benzoic acid), presented in Fig. 1, belongs to the group of aromatic amino acids. This compound is of specific interest because of its biological activity-it is a potential inhibitor of prostaglandin synthesis, the presence of which is closely associated with inflammatory processes [6]. It also displays analgesic, anti-inflammatory, antipyretic, antioxidant and 
<smiles>Cc1cccc(Nc2ccccc2C(=O)O)c1C</smiles>

Fig. 1 Molecular structure of mefenamic acid

antiproliferative activity. Therefore, it is an important nonsteroidal drug used for treatment moderate pain of various origins (dysmenorrhea, rheumatic diseases, sciatica, headache, premenstrual syndrome, postoperative, posttraumatic and dental pains) [7, 8]. Also, mefenamic acid shows therapeutic effects as anticancer agent (particularly colon and liver cancer cell lines) [9, 10]. Furthermore, it is applied for the preparation of new potent antiinflammatory and analgesic agents [11-13].

The biological activity of NSAIDs may be changed or improved due to the formation of metal complexes [14]. As long as mefenamic acid can form complexes with many metal ions, the formation of metal complexes plays important and multiple roles in biological systems. Metalbinding substances, many of which function by chelation, form a class of substances which have provided diverse useful drugs and other substances of value in selective toxicity. They have found many uses in veterinary and human medicine [15].

In recent years, new mefenamic acid complexes with metal ions have been synthesized and characterized for their potential applications in various fields. The complex of mefenamic acid with bismuth(III) [16] shows excellent in vitro activity against Helicobacter pylori, the bacterium which is mainly responsible for gastric, peptic and duodenal ulcers and gastric cancer $[17,18]$. The complexes of mefenamic acid with $\mathrm{Mn}(\mathrm{II}), \mathrm{Co}(\mathrm{II}), \mathrm{Ni}(\mathrm{II}), \mathrm{Zn}(\mathrm{II})$ and $\mathrm{Cu}(\mathrm{II})$ show antioxidant properties and inhibitory effect against the soybean lipoxygenase [19]. Furthermore, the complex with $\mathrm{Mn}$ (II) exhibits the highest antioxidant and anti-inflammatory effect, and the complex with $\mathrm{Cu}$ (II) has antitumor activity comparable to that of a cisplatin. Also, Feng et al. [20] showed that three mefenamic acid complexes with $\mathrm{Mn}(\mathrm{II})$ obtained by them have a higher inhibitory activity against the lipoxygenase than the parent ligand, i.e., mefenamic acid. Additionally, the complexes of this amino acid with $\mathrm{Ni}(\mathrm{II}), \mathrm{Zn}$ (II) and $\mathrm{Cu}$ (II) demonstrate high affinity to bovine and human serum albumins [21-23].

It should be noted that, in most cases, the complexes are mononuclear (and synthetized with M:L ratios 1:1, 1:2, 1:3 and 1:4). Based on the study of mefenamic acid complexes with $\mathrm{Fe}(\mathrm{III})$ ions, it has been shown that mononuclear complexes were formed, but in the presence of an excess of $\mathrm{Fe}(\mathrm{III})$ ions, a binuclear complex was obtained [24].
Mononuclear complexes of mefenamic acid with rare earth elements have already been obtained by mixing ammonium mefenamate solution and appropriate rare earth chlorides or nitrates. Afterwards, they have been analyzed in order to introduce their physical, spectroscopic and thermal properties [25, 26]. Polynuclear metal complexes exhibit a fascinating variety of unusual symmetries and structural patterns [27]. The biological relevance of some of these compounds and their potentially important applications as advanced materials adds to their interest and significance [28]. Thus, our study has focused on the preparation of dinuclear complexes of mefenamic acid with $\mathrm{La}(\mathrm{III})$, $\mathrm{Nd}(\mathrm{III}), \mathrm{Sm}(\mathrm{III}), \mathrm{Eu}(\mathrm{III}) \mathrm{Gd}(\mathrm{III})$, and $\mathrm{Tb}(\mathrm{III})$ ions in the solid state, as well as on the analysis of their composition and properties by using elemental analysis, gravimetry, thermogravimetry, differential scanning calorimetry (DSC), IR and UV-Vis spectroscopy, molar conductivity, ${ }^{1} \mathrm{H}$ NMR spectroscopy and X-ray powder diffraction (XRD). We hope that the synthesis of these complexes will provide not only theoretical information on coordination chemistry, but also will give important information for further study of biological activities of these complexes as potential chemotherapeutic agents.

\section{Experimental}

\section{Materials and measurements}

Mefenamic acid and the rare earth(III) oxides (99.9\%) were obtained from Sigma-Aldrich. The rare earth(III) chlorides $\left(1 \times 10^{-2} \mathrm{~mol} \mathrm{dm}^{-3}\right)$ were prepared by dissolving an appropriately weighted amounts of their oxides in concentrated hydrochloric acid $\left(d=1.19 \mathrm{~kg} \mathrm{dm}^{-3}\right)$. The acid excess was evaporated, and the residues were dissolved in redistilled water. Methanol, sodium hydroxide and hydrochloric acid were acquired from $\mathrm{POCH}$, Poland, while DMSO was from Merck. All the used chemicals were of analytical grade.

The contents of $\mathrm{C}, \mathrm{H}$ and $\mathrm{N}$ in the complexes were determined with the usage of a Vario EL elemental analyzer. (Elementar, Germany). The metal content was determined by gravimetric method, and the water content was calculated on the basis of the results obtained by the thermogravimetric method. The chlorine content was determined by the Schöniger method. The FT-NMR spectrum for mefenamic acid and $\mathrm{La}(\mathrm{III})$ complex was recorded on a FT-NMR spectrophotometer, $500 \mathrm{MHz}$ (Bruker). The UV-Vis spectra of the compounds in methanol and DMSO were performed with a V-670 UVVis-NIR spectrophotometer (Jasco, Japan). Infrared spectra were carried out in $\mathrm{KBr}$ pellets in $4000-400 \mathrm{~cm}^{-1}$ on an Alpha FT-IR spectrophotometer (Bruker, Germany). The 
X-ray powder analysis of solid complexes samples was carried out by means of a Bruker D2 Phaser powder diffractometer, using $\mathrm{Cu} \mathrm{K} \alpha$ radiation $(\lambda=1.5406 \AA)$. The measurements were taken over the range of $2 \theta=10-100^{\circ}$. Solubility study was carried out in methanol and DMSO at $(20 \pm 1)^{\circ} \mathrm{C}$. Molar conductance at room temperature was measured in $1 \times 10^{-3} \mathrm{~mol} / \mathrm{dm}^{3}$ DMSO solution using a CX-505 conductometer (Elmetron, Poland). Thermogravimetric analysis of the obtained lanthanide complexes was carried out using TGA/DSC1 apparatus (Mettler Toledo) in dynamic nitrogen atmosphere $\left(50 \mathrm{~mL} \mathrm{~min}{ }^{-1}\right)$ in the temperature range of $25-1000{ }^{\circ} \mathrm{C}$ at a heating rate $10{ }^{\circ} \mathrm{C} \min ^{-1}$. Evolved gas analysis was also performed applying combined TG-FTIR technique. TG instrument was coupled with FTIR apparatus Nicolet iS10 (Thermo Scientific) by a transfer line heated at $220{ }^{\circ} \mathrm{C}$. The differential scanning calorimetry (DSC) of the synthesized complexes was performed with a Mettler Toledo DSC$822 \mathrm{e}$ calorimeter in nitrogen atmosphere at a heating rate $10{ }^{\circ} \mathrm{C} \mathrm{min}{ }^{-1}$ from -30 to $250{ }^{\circ} \mathrm{C}$.

\section{Synthesis of the complexes}

The synthesis of $\mathrm{La}(\mathrm{III}), \mathrm{Nd}(\mathrm{III}), \mathrm{Sm}(\mathrm{III}), \mathrm{Eu}(\mathrm{III}), \mathrm{Gd}(\mathrm{III})$ and $\mathrm{Tb}$ (III) complexes with mefenamic acid was carried out in aqueous-methanol solution according to the molar ratio of $\mathrm{Ln}^{3+}$ to ligand $1: 2$ at $70{ }^{\circ} \mathrm{C}$ under stirring. A stock solution of appropriate lanthanide ions $\left(1 \times 10^{-2} \mathrm{~mol} \mathrm{dm}^{-3}\right)$ was added into a hot and saturated solution of mefenamic acid in methanol $\left(1 \times 10^{-2} \mathrm{~mol} / \mathrm{dm}^{3}\right)$ and then diluted with water to the ratio of methanol to water $1: 1$. Afterwards, the $\mathrm{pH}$ of the mixture was adjusted to $6-6.5$ by addition of $0.5 \mathrm{~mol} / \mathrm{dm}^{3} \mathrm{NaOH}$ solution. The resulting solid complexes appeared as colored precipitates. The mixture was maintained at $60{ }^{\circ} \mathrm{C}$ for $1 \mathrm{~h}$ and then left at room temperature for $24 \mathrm{~h}$. Next, the precipitates were filtered, washed with deionized water and methanol until no chloride ions could be found and finally dried in air at room temperature.

\section{Results and discussion}

\section{Composition and physicochemical properties of the complexes}

The composition of the obtained complexes was identified by elemental analysis, electronic and infrared spectra, thermogravimetric analysis and differential scanning calorimetry. The synthesized complexes have yellowgreen color. They are insoluble in water and poorly soluble in other polar solvents (methanol, ethanol and acetonitrile). The solubility of the complexes in methanol is of the order of $10^{-5} \mathrm{~mol} \mathrm{dm}^{-3}$, with the exception of the lanthanum complex which is more soluble in methanol. In this case, the solubility value is about $10^{-4} \mathrm{~mol} \mathrm{dm}^{-3}$. All the compounds have a slightly greater solubility in DMSO (approximately $10^{-3} \mathrm{~mol} \mathrm{dm}^{-3}$ ).

The molar conductance of their $10^{-3} \mathrm{~mol} \mathrm{dm}^{-3}$ DMSO solutions was varied from 14 to $34 \Omega^{-1} \mathrm{~cm}^{2} \mathrm{~mol}^{-1}$, which indicates that the complexes are nonelectrolytes [29].

The XRD patterns (Fig. 2) show that only complex with $\mathrm{La}$ (III) ions has crystalline structure and other analyzed compounds are amorphous. The characteristic XRD peaks of the lanthanum complex are observed at $11.8^{\circ}, 17.9^{\circ}$, $23.8^{\circ}$ and $25.6^{\circ}(2 \theta)$. These peaks are distinguished by one of the polymorphic forms of mefenamic acid (polymorph II) [30] as well as sodium and iron mefenamate [19].

\section{Elemental analysis}

The results of the chemical analysis and formulae of the prepared solid complexes are presented in Table 1. It was found that the composition of the lanthanum complex differs significantly from that of the other complexes.

The ease of hydrolysis of the lanthanide ions, and tendency to form a lanthanide-hydroxo species makes that suitable hydroxo complexes can be formed by reaction with organic ligand [31]. The studied complexes were formed in aqueous solutions at $\mathrm{pH}$ about 6.5 when in the solution both $\mathrm{Ln}(\mathrm{OH})^{2+}$ and $\mathrm{Ln}(\mathrm{OH})_{2}^{+}$ions occur [32], so may be assume that the $\mathrm{Ln}(\mathrm{OH})^{+}$ions are present in the complex. Additionally, elemental analysis excluded the presence of chlorine in the obtained compounds. Therefore, the formula $\mathrm{La}_{2}\left(\mathrm{C}_{15} \mathrm{H}_{14} \mathrm{NO}_{2}\right)_{5}(\mathrm{OH})$ was proposed for $\mathrm{La}$ (III) complex and $\mathrm{Ln}_{2}\left(\mathrm{C}_{15} \mathrm{H}_{14} \mathrm{NO}_{2}\right)_{3}(\mathrm{OH})_{3} \cdot \mathrm{nH}_{2} \mathrm{O}$ for the other complexes where $\mathrm{Ln}$ means $\mathrm{Nd}, \mathrm{Sm}, \mathrm{Eu}, \mathrm{Gd}, \mathrm{Tb}$ and

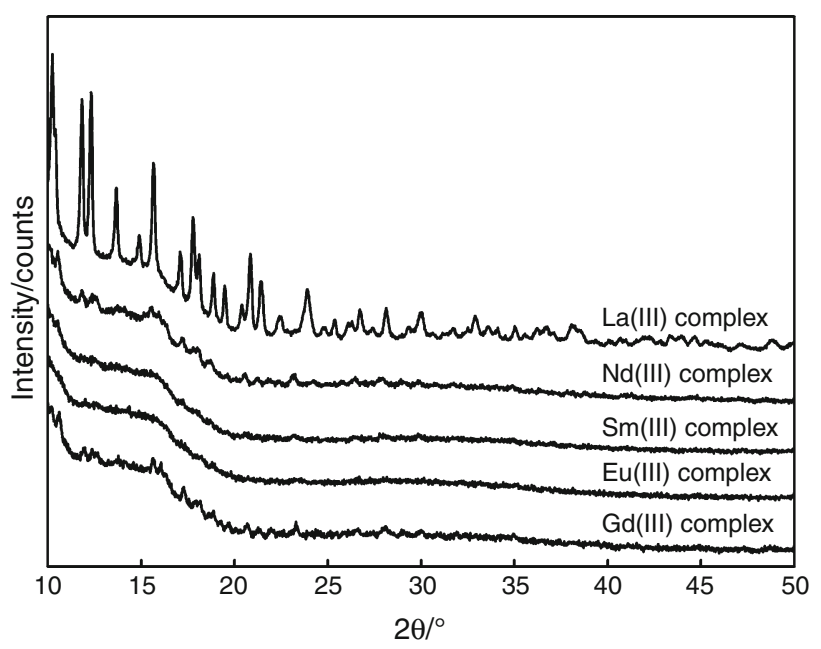

Fig. 2 X-ray powder diffraction patterns of $\operatorname{Ln}(\mathrm{III})$ complexes with mefenamic acid 
Table 1 Results of chemical analysis and molar conductance data of $\operatorname{Ln}(\mathrm{III})$ complexes with mefenamic acid

\begin{tabular}{|c|c|c|c|c|c|c|}
\hline \multirow[t]{2}{*}{ Complex } & \multirow{2}{*}{$\begin{array}{l}\text { Molecular mass/ } \\
\mathrm{g} \mathrm{mol}^{-1}\end{array}$} & \multicolumn{4}{|c|}{ Mass fraction $/ \%$ found (calculated) } & \multirow{2}{*}{$\begin{array}{l}\text { Molar conductance/ } \\
\Omega^{-1} \mathrm{~cm}^{2} \mathrm{~mol}^{-1}\end{array}$} \\
\hline & & Ln & $\mathrm{C}$ & $\mathrm{H}$ & $\mathrm{N}$ & \\
\hline $\mathrm{La}_{2}\left(\mathrm{C}_{15} \mathrm{H}_{14} \mathrm{NO}_{2}\right)_{5} \mathrm{OH}$ & 1469.19 & $17.98(18.57)$ & $59.76(60.20)$ & $4.78(4.78)$ & $4.62(4.68)$ & 34 \\
\hline $\mathrm{Nd}_{2}\left(\mathrm{C}_{15} \mathrm{H}_{14} \mathrm{NO}_{2}\right)_{3}(\mathrm{OH})_{3} \cdot 2 \mathrm{H}_{2} \mathrm{O}$ & 1096.35 & $26.38(26.31)$ & $50.06(49.30)$ & $4.48(4.51)$ & $3.88(3.83)$ & 17 \\
\hline $\mathrm{Sm}_{2}\left(\mathrm{C}_{15} \mathrm{H}_{14} \mathrm{NO}_{2}\right)_{3}(\mathrm{OH})_{3} \cdot 3 \mathrm{H}_{2} \mathrm{O}$ & 1126.61 & $26.44(26.69)$ & $47.76(47.97)$ & $4.47(4.56)$ & $3.71(3.73)$ & 16 \\
\hline $\mathrm{Eu}_{2}\left(\mathrm{C}_{15} \mathrm{H}_{14} \mathrm{NO}_{2}\right)_{3}(\mathrm{OH})_{3} \cdot 3.5 \mathrm{H}_{2} \mathrm{O}$ & 1138.82 & $26.15(26.48)$ & $46.41(47.46)$ & $4.62(4.60)$ & $3.76(3.69)$ & 18 \\
\hline $\mathrm{Gd}_{2}\left(\mathrm{C}_{15} \mathrm{H}_{14} \mathrm{NO}_{2}\right)_{3}(\mathrm{OH})_{3} \cdot 3 \mathrm{H}_{2} \mathrm{O}$ & 1140.39 & $27.22(27.58)$ & $47.77(47.39)$ & $4.39(4.51)$ & $3.72(3.69)$ & 14 \\
\hline $\mathrm{Tb}_{2}\left(\mathrm{C}_{15} \mathrm{H}_{14} \mathrm{NO}_{2}\right)_{3}(\mathrm{OH})_{3} \cdot 3 \mathrm{H}_{2} \mathrm{O}$ & 1143.73 & $27.67(27.79)$ & $47.90(47.25)$ & $4.26(4.49)$ & $3.74(3.67)$ & 15 \\
\hline
\end{tabular}

$n=2$ for $\mathrm{Nd}, n=3$ for $\mathrm{Sm}, \mathrm{Gd}$ and $\mathrm{Tb}$ as well as $n=4$ for $\mathrm{Eu}$.

\section{UV-Vis study}

The UV-Vis spectra of the mefenamic acid and the lanthanide complexes were recorded in methanol and DMSO. The spectral data are summarized in Table 2.

Figure 3 shows the absorption spectra of mefenamic acid and its europium complex in methanol and DMSO. The spectra of the other complexes were similar. The absorption spectrum of mefenamic acid is characterized by two bands: band I with maximum at around $350 \mathrm{~nm}$ and band II with maximum around $280 \mathrm{~nm}$. The band I corresponds to $\pi \rightarrow \pi^{*}$ transition within the heterocyclic moiety (intramolecular hydrogen bonding ring) of the mefenamic acid molecule. The band II can be ascribed to $\pi \rightarrow \pi^{*}$ transition of the benzenoid system of mefenamic acid $[33,34]$.

The UV-Vis spectrum of mefenamic acid in DMSO is characterized by a slight bathochromic shift compared to the spectrum of this compound in methanol. The changes indicate that the excited states are more dipolar than corresponding ground states and, what is more, that electronic transition energy decreases, because the more dipolar excited state is stabilized by more polar solvent (DMSO) [35].

As regards the electronic spectra of the obtained complexes, the shifts of the characteristic bands were observed

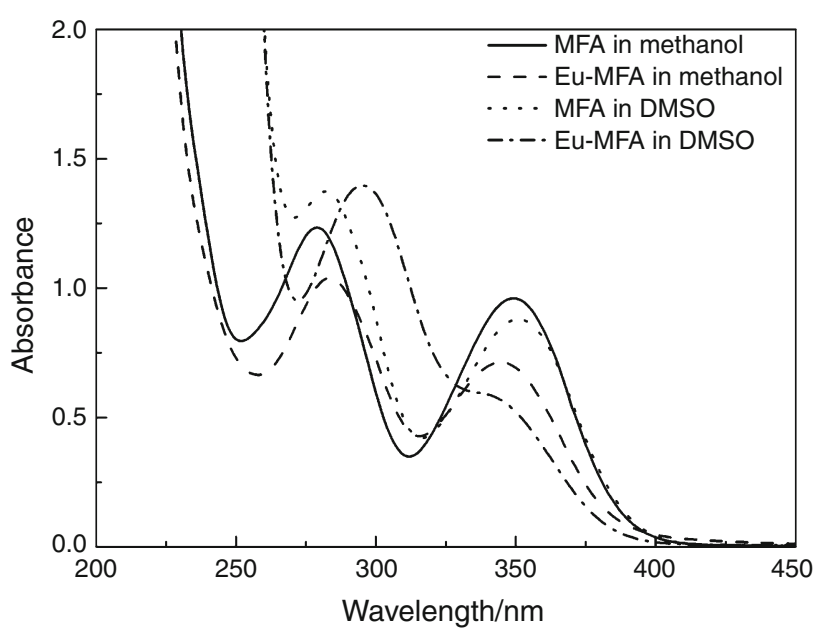

Fig. 3 Absorption spectra of mefenamic acid (MFA) and Eu(III) complex with mefenamic acid (Eu-MFA) in methanol and DMSO

comparable to the ones of mefenamic acid, what confirms complex formation. The changes are very similar for all investigated complexes. Moreover, the influence of solvent polarity can be noted. The hypsochromic shift of the band I by $4-5 \mathrm{~nm}$ in methanol and $12-13 \mathrm{~nm}$ in DMSO was observed. The band II was shifted bathochromically by 5-6 $\mathrm{nm}$ in methanol and $13 \mathrm{~nm}$ in DMSO. In addition, the noticeable absorbance decrease of the band II in the spectra of the complexes in DMSO was observed. The study shows that the absorption spectra of the obtained complexes are

Table 2 Spectral data $\left(\lambda_{\max }, \mathrm{nm}\right)$ of mefenamic acid and its complexes with $\mathrm{Ln}(\mathrm{III})$ ions in methanol and DMSO solutions

\begin{tabular}{|c|c|c|c|c|c|c|c|}
\hline \multirow[t]{2}{*}{ Solvents } & \multirow[t]{2}{*}{ MFA } & \multicolumn{6}{|c|}{ Complex } \\
\hline & & $\mathrm{La}(\mathrm{III})$ & $\mathrm{Nd}(\mathrm{III})$ & $\mathrm{Sm}(\mathrm{III})$ & $\mathrm{Eu}(\mathrm{III})$ & $\mathrm{Gd}(\mathrm{III})$ & $\mathrm{Tb}(\mathrm{III})$ \\
\hline \multirow[t]{2}{*}{ Methanol } & 279 & 284 & 284 & 284 & 283 & 283 & 283 \\
\hline & 349 & 344 & 345 & 345 & 345 & 345 & 345 \\
\hline \multirow[t]{2}{*}{ DMSO } & 282 & 295 & 295 & 295 & 295 & 294 & 294 \\
\hline & 351 & 338 & 338 & 338 & 338 & 338 & 338 \\
\hline
\end{tabular}


determined by the coordinated organic ligand what is typical for lanthanide complexes [36].

\section{IR spectra}

The IR spectra provide valuable information regarding the nature of the functional group attached to the metal atom. The IR spectra of the six rare earth complexes and mefenamic acid were performed with $\mathrm{KBr}$ pellets in the range of $4000-400 \mathrm{~cm}^{-1}$ and have been used to define the structure of the synthetized compounds. They were interpreted on the basis of main bands of mefenamic acid and its complexes that are given in Table 3.

The IR spectra of all complexes are very similar; nevertheless, the comparison of these spectra with that of mefenamic acid shows important spectral changes (Fig. 4). Moreover, the IR spectra of all complexes are almost identical (slight differences concern the intensity of bands, not their location) with the exception of the spectrum of $\mathrm{La}(\mathrm{III})$ complex which differs significantly in the range of $3800-3400 \mathrm{~cm}^{-1}$. In this region for $\mathrm{Nd}(\mathrm{III}), \mathrm{Sm}(\mathrm{III})$, $\mathrm{Eu}(\mathrm{III}), \mathrm{Gd}(\mathrm{III})$ and $\mathrm{Tb}(\mathrm{III})$ complexes, the broad envelope band with a high intensity appears. This indicates the presence of weak hydrogen bonds that stabilize the structure of the complexes [37, 38]. This band is connected with the presence of water in the obtained complexes, because it is the characteristic band for the $\mathrm{OH}$ stretching vibrations (asymmetric and symmetric) in water molecule. The presence of water in these complexes was confirmed by the thermal analysis. For La(III) complex, this band is slightly outlined.
The stretching vibrations of the $\mathrm{NH}$ group of mefenamic acid are observed at a wavelength of $3310 \mathrm{~cm}^{-1}$, and for the synthesized complexes, only a small shift of this band toward higher frequencies is observed. Therefore, we concluded that nitrogen atom of the amino group does not participate in the coordination of the metal ion [15, 24, 39]. Examined spectra exhibit a band derived from asymmetric and symmetric stretching vibrations of methyl group observed at 2974-2858 and $2969-2859 \mathrm{~cm}^{-1}$ for mefenamic acid and complexes, respectively. In the spectrum of mefenamic acid, the broadband characteristic for $\mathrm{OH}$ stretching vibrations of the carboxyl group is observed in the range of $3300-2500 \mathrm{~cm}^{-1}$, but in the spectra of complexes this band disappears.

It has been found that the greatest changes occurred in the frequency range in which the bands characteristic for the carboxyl group in mefenamic acid are present, i.e., the disappearance of the band assigned to the stretching vibrations of the carbonyl group at $1648 \mathrm{~cm}^{-1}$. On the other hand, in the spectra of the complexes, two new bands appear at $1613-1614$ and $\sim 1390 \mathrm{~cm}^{-1}$. They can be attributed to the asymmetric and symmetric stretching vibrations of the $\mathrm{COO}^{-}$group, respectively. The IR band shift of the carbonyl group toward the smaller wavenumber is probably connected with the lengthening of the $\mathrm{C}-\mathrm{O}$ bond in the carboxylate group, thereby a reduction in the force constant. The complexation may be the reason of this phenomenon. Presented data indicate that the $\mathrm{COO}^{-}$group is involved in the coordination of the studied lanthanide ions. The differences $(\Delta v)$ between the wavenumbers of asymmetric and symmetric stretching vibrations for the

Table 3 IR bands of mefenamic acid, sodium mefenamate [37] and Ln(III) complexes with mefenamic acid

\begin{tabular}{|c|c|c|c|c|c|c|c|}
\hline Compound & $v_{(\mathrm{NH})}$ & $v_{(\mathrm{COOH})}$ & $\mathrm{V}_{\mathrm{as}\left(\mathrm{COO}^{-}\right)}$ & $v_{\mathrm{s}\left(\mathrm{COO}^{-}\right)}$ & $\Delta v^{*}$ & $\delta_{(\mathrm{NH})}$ & $v_{(\operatorname{Ln}-O)}$ \\
\hline Mefenamic acid & 3310 & 1648 & & & - & $\begin{array}{l}1576 \\
1510\end{array}$ & - \\
\hline Sodium mefenamate & & & 1612 & 1373 & 239 & & \\
\hline $\mathrm{La}_{2}\left(\mathrm{C}_{15} \mathrm{H}_{14} \mathrm{NO}_{2}\right)_{5}(\mathrm{OH})$ & 3339 & - & 1614 & 1394 & 220 & $\begin{array}{l}1579 \\
1506\end{array}$ & 429 \\
\hline $\mathrm{Nd}_{2}\left(\mathrm{C}_{15} \mathrm{H}_{14} \mathrm{NO}_{2}\right)_{3}(\mathrm{OH})_{3} \cdot 2 \mathrm{H}_{2} \mathrm{O}$ & 3305 & - & 1614 & 1390 & 224 & $\begin{array}{l}1578 \\
1497\end{array}$ & 435 \\
\hline $\mathrm{Sm}_{2}\left(\mathrm{C}_{15} \mathrm{H}_{14} \mathrm{NO}_{2}\right)_{3}(\mathrm{OH})_{3} \cdot 3 \mathrm{H}_{2} \mathrm{O}$ & 3310 & - & 1614 & 1394 & 220 & $\begin{array}{l}1578 \\
1497\end{array}$ & 437 \\
\hline $\mathrm{Eu}_{3}\left(\mathrm{C}_{15} \mathrm{H}_{14} \mathrm{NO}_{2}\right)_{3}(\mathrm{OH})_{3} \cdot 3.5 \mathrm{H}_{2} \mathrm{O}$ & 3318 & - & 1614 & 1398 & 216 & $\begin{array}{l}1578 \\
1497\end{array}$ & 437 \\
\hline $\mathrm{Gd}_{2}\left(\mathrm{C}_{15} \mathrm{H}_{14} \mathrm{NO}_{2}\right)_{3}(\mathrm{OH})_{3} \cdot 3 \mathrm{H}_{2} \mathrm{O}$ & 3315 & - & 1614 & 1398 & 216 & $\begin{array}{l}1578 \\
1497\end{array}$ & 439 \\
\hline $\mathrm{Tb}_{2}\left(\mathrm{C}_{15} \mathrm{H}_{14} \mathrm{NO}_{2}\right)_{3}(\mathrm{OH})_{3} \cdot 3 \mathrm{H}_{2} \mathrm{O}$ & 3335 & - & 1613 & 1397 & 216 & $\begin{array}{l}1578 \\
1497\end{array}$ & 440 \\
\hline
\end{tabular}

$* v_{\mathrm{as}\left(\mathrm{COO}^{-}\right)}-\mathrm{v}_{\mathrm{s}\left(\mathrm{COO}^{-}\right)}$ 
Fig. 4 FTIR spectra of mefenamic acid, $\mathrm{La}(\mathrm{III})$ and Eu(III) complexes with mefenamic acid

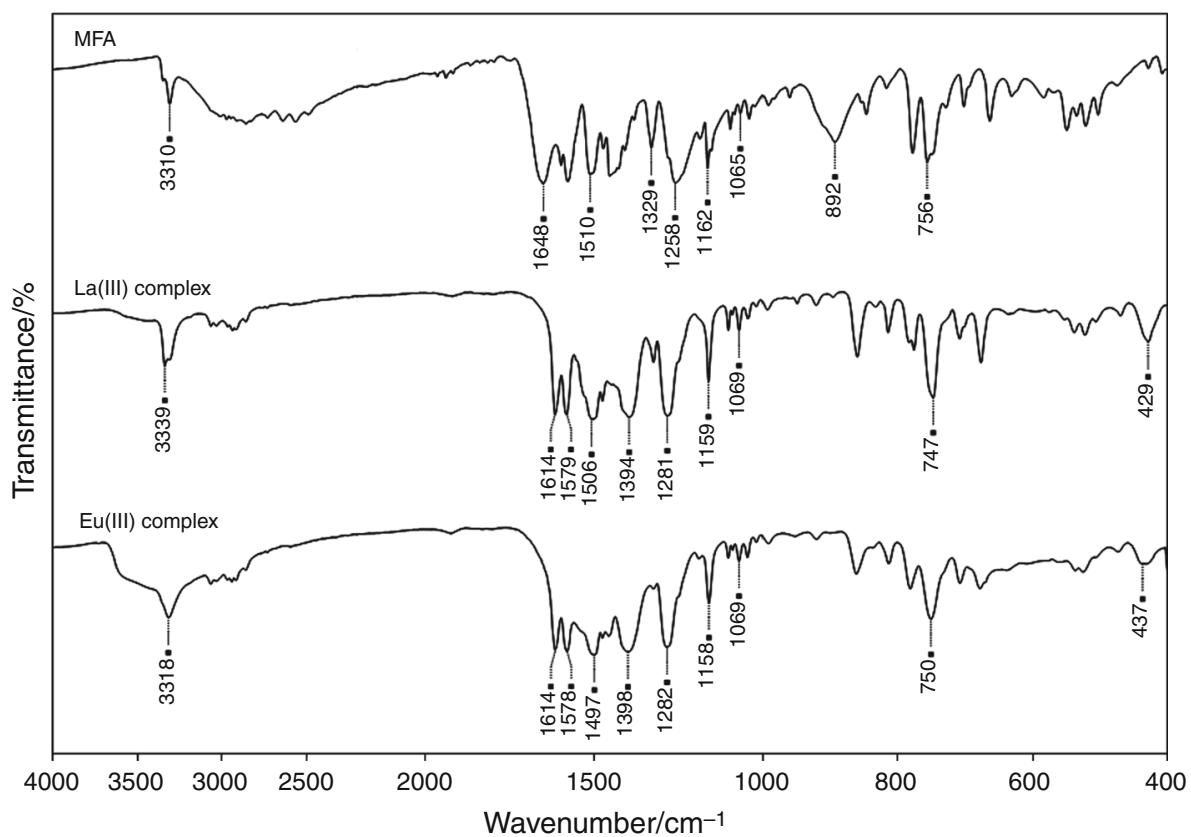

carboxylate group were calculated and compared with the value of $\Delta v$ obtained for sodium salt of mefenamic acid. In the case of NaMFA, the value of $\Delta v=239 \mathrm{~cm}^{-1}$ [40] and for the complexes the values of $\Delta v$ are about $220 \mathrm{~cm}^{-1}$. Based on the value of $\Delta v$ for the obtained complexes, the monodentate type of the carboxylate group can be unambiguously excluded, while bidentate coordination is possible [41, 42]. The smaller $\Delta v$ values of the complex suggest the existence of the bridge-type or chelate-type bonding between the metal and ligand [39, 43]. Furthermore, taking into account the specific characteristics of dimeric and polymeric lanthanide complexes (due to their large number of coordination and the absence of a special preference for the coordination geometry), the mixed bridge-chelate-type bonding nature of the carboxylate group is also possible.

In the spectra of the complexes, the bands associated with the deformation $\mathrm{CO}-\mathrm{H}$, stretching $\mathrm{C}-\mathrm{O}$ and bending $\mathrm{OH}$ (out of plane) vibration are not observed. Those bands are present in the spectrum of mefenamic acid at 1426 , 1329 and $892 \mathrm{~cm}^{-1}$, respectively.

In the low-frequency region of the complexes spectra, additional bands of medium intensity occur in the 420- to $440-\mathrm{cm}^{-1}$ range and these bands could be assigned as metal-oxygen stretching vibrations. These sensitive bands exhibit a regular shift toward higher wavenumbers in the order from $\mathrm{La}$ (III) to $\mathrm{Tb}$ (III) complexes, which means that the stretching frequencies of Ln-O bonds increase with the increasing of atomic number in the series of lanthanide ions. Thus, the force constant of the lanthanide metal-oxygen bond also increases, which is due to the increase in covalency of the $\mathrm{Ln}-\mathrm{O}$ bond in the obtained compounds [44].

\section{${ }^{1}$ H NMR spectra}

${ }^{1} \mathrm{H}$ NMR spectra (recorded in DMSO- $\mathrm{d}_{6}$ and in $\mathrm{D}_{2} \mathrm{O}$ DMSO- $\mathrm{d}_{6}$ system) were acquired for mefenamic acid and the synthesized La(III) complex to investigate possible coordination modes. Assignments of the resonances of aromatic protons and protons in methyl groups of mefenamic acid were made by considering the available literature data [45]. Comparison of the ligand and the complex spectra revealed that the significant changes appeared only for the signals which are commonly assigned to the protons of carboxyl and amino group. In mefenamic acid spectrum recorded in $\mathrm{DMSO}-\mathrm{d}_{6}$ solution, the signals at 12.98 and $9.45 \mathrm{ppm}$ correspond to mentioned protons, respectively. Disappearance of these signals in MFA spectra registered in $\mathrm{D}_{2} \mathrm{O}$-DMSO- $\mathrm{d}_{6}$ system confirmed correct assignment.

In the spectrum of La(III) complex in DMSO- $\mathrm{d}_{6}$ disappears the signal of the proton of carboxylate group and the signal of proton of amino group shifts to 10.27 . The disappearance of proton signal of the $\mathrm{COOH}$ group in La(III) complex confirms the involvement of this group in the creation of the complex. The existence of the $\mathrm{HN}$ resonance in the ${ }^{1} \mathrm{H}-\mathrm{NMR}$ spectra indicates that the nitrogen atom remains protonated in the obtained complex. The significant shift of NH proton can be attributed to the break of an intramolecular hydrogen bond between the carboxyl and amino groups that occurs in mefenamic acid molecule. 
Thus, it can be concluded that La(III) complex with mefenamic acid was formed.

\section{Thermal analysis}

Thermal analysis of lanthanide complexes was performed in order to study the nature of water in the investigated compounds, their thermal stability, as well as decomposition modes under controlled heating rate. The measurements were taken in nitrogen atmosphere within $25-1000{ }^{\circ} \mathrm{C}$ at a heating rate of $10{ }^{\circ} \mathrm{C} \mathrm{min}^{-1}$.

The curves of TG, DTG and DSC for the particular compounds are shown in Fig. 5, whereas their interpretation is presented in Table 4.

The analysis of the TG and DSC curves demonstrates that they undergo gradual decomposition as the temperature increases. With the exception of the complex with lanthanum ion, where decomposition is a three-step process, all other complexes are characterized by four-step decomposition.

The first step of decomposition on the TG curves occurs within temperature range $30-190{ }^{\circ} \mathrm{C}$ and is centered at $85^{\circ} \mathrm{C}$ (mass loss $=3.5 \%$ ), $80{ }^{\circ} \mathrm{C}$ (mass loss $=4.6 \%$ ), $58{ }^{\circ} \mathrm{C}$ (mass loss $=5.1 \%$ ), $59{ }^{\circ} \mathrm{C}$ (mass loss $=4.48 \%$ ) and $58{ }^{\circ} \mathrm{C}$ (mass loss $=4.6 \%$ ), respectively, for $\mathrm{Nd}(\mathrm{III}$ ), $\mathrm{Sm}(\mathrm{III}), \mathrm{Eu}(\mathrm{III}), \mathrm{Gd}(\mathrm{III})$ and $\mathrm{Tb}(\mathrm{III})$ complexes. This decomposition step is related to dehydration process and corresponds to the loss of two water molecules for neodymium complex, three molecules of water for samarium, gadolinium and terbium complexes and 3.5 molecules of water in the case of europium complex. For lanthanum complex, no peak on DTG curve in temperature range up to $350{ }^{\circ} \mathrm{C}$ is observed, indicating that the anhydrous compound was received.

Temperature range of dehydration as well as value of dehydration enthalpy can be used to study the nature of water in metal complexes [46, 47]. The presence of crystallization or coordination water has influence on the initial course of the process of thermal compounds decomposition. In order to establish the nature of water molecules in the obtained hydrated metal complexes additionally, the DSC technique was employed. Measurements were taken in temperature range from -30 to $250{ }^{\circ} \mathrm{C}$. The broad, endothermic peaks are observed on the DSC curves obtained for complexes of $\operatorname{Ln}(\mathrm{III})$ with mefenamic acid for dehydration stage (Fig. 6). The results indicate that this process is a single step. Thus, in the synthesized compounds, one type of water molecules is present [48].

Based on the obtained data, the values of the dehydration enthalpy were calculated and the results are summarized in Table 5. The dehydration enthalpies per one water molecule found for investigated complexes are between 17 and $22 \mathrm{~kJ}$. Low values of dehydration enthalpies indicate that the water molecules are weakly bonded to the ligand and probably participate in the formation of hydrogen bond with mefenamate ligand. Hence, the obtained lanthanide compounds contain only crystallization water molecules $[49,50]$.

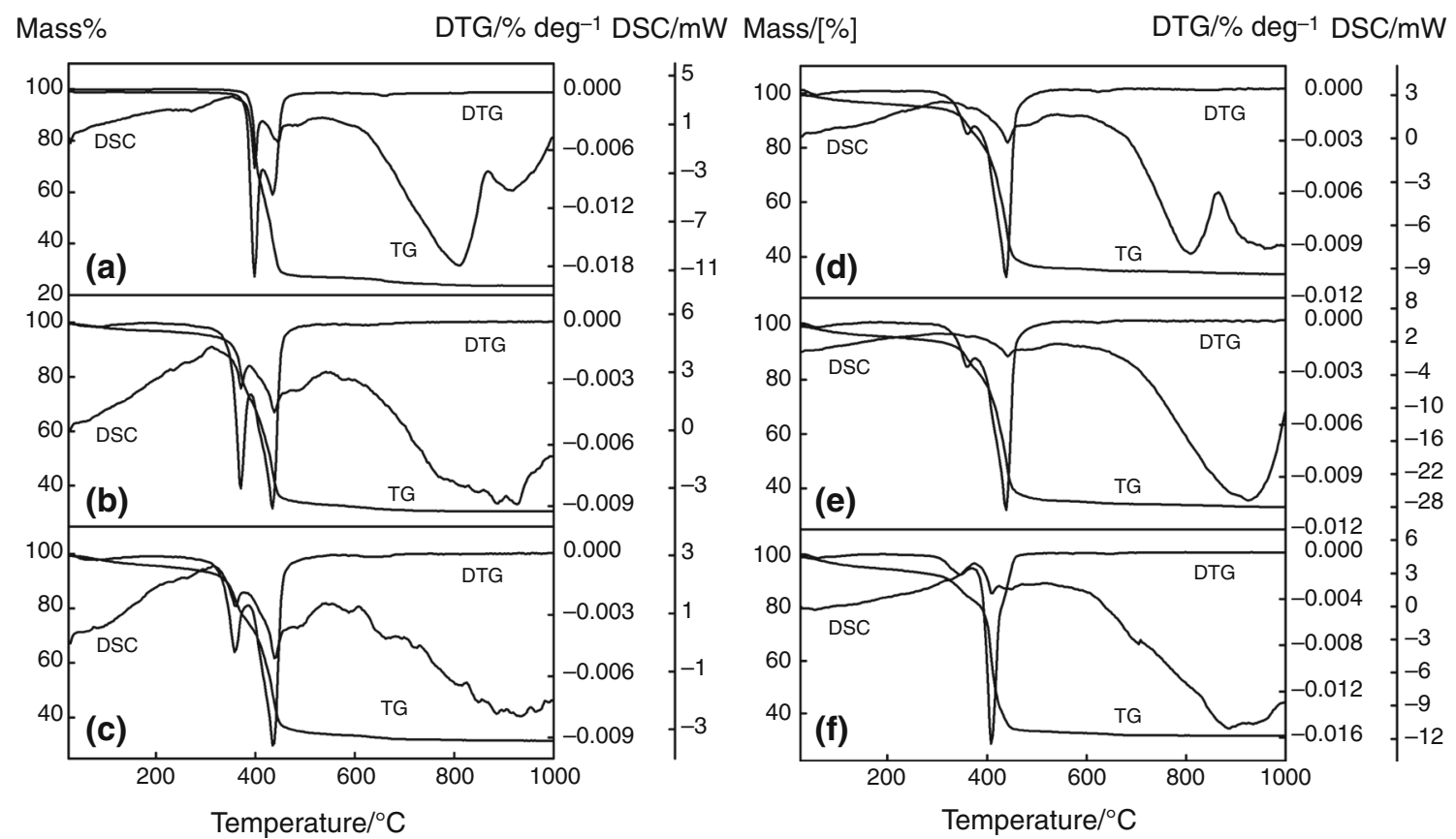

Fig. 5 TG, DTG and DSC curves for: (a) La(III), (b) Nd(III), (c) Sm(III), (d) Eu(III), (e) Gd(III), (f) Tb(III) complexes with mefenamic acid 
Table 4 Thermal decomposition data for Ln(III) complexes with mefenamic acid in nitrogen atmosphere

\begin{tabular}{|c|c|c|c|c|c|}
\hline Complex & Stage & Temperature range $/{ }^{\circ} \mathrm{C}$ & $\mathrm{T}_{\max .}^{\mathrm{DTG}} /{ }^{\circ} \mathrm{C}$ & $\Delta \mathrm{m} / \%$ & Residue/\% found (calc.) \\
\hline \multirow[t]{3}{*}{$\mathrm{La}_{2}\left(\mathrm{C}_{15} \mathrm{H}_{14} \mathrm{NO}_{2}\right)_{5}(\mathrm{OH})$} & I & $30-410$ & 399 & 39.7 & \multirow[t]{3}{*}{$23.2(22.2)$} \\
\hline & II & $410-590$ & 436 & 35.3 & \\
\hline & III & $590-1000$ & 660 & 3.0 & \\
\hline \multirow[t]{4}{*}{$\mathrm{Nd}_{2}\left(\mathrm{C}_{15} \mathrm{H}_{14} \mathrm{NO}_{2}\right)_{3}(\mathrm{OH})_{3} \cdot 2 \mathrm{H}_{2} \mathrm{O}$} & I & $30-180$ & 85 & 3.5 & \multirow[t]{4}{*}{$29.4(28.6)$} \\
\hline & II & $180-390$ & 372 & 26.1 & \\
\hline & III & $390-520$ & 436 & 40.6 & \\
\hline & IV & $520-1000$ & 626 & 2.8 & \\
\hline \multirow[t]{4}{*}{$\mathrm{Sm}_{2}\left(\mathrm{C}_{15} \mathrm{H}_{14} \mathrm{NO}_{2}\right)_{3}(\mathrm{OH})_{3} \cdot 3 \mathrm{H}_{2} \mathrm{O}$} & I & $30-190$ & 80 & 4.6 & \multirow[t]{4}{*}{$30.8(31.7)$} \\
\hline & II & $190-390$ & 360 & 21.1 & \\
\hline & III & $390-550$ & 437 & 41.1 & \\
\hline & IV & $550-1000$ & 644 & 2.4 & \\
\hline \multirow[t]{4}{*}{$\mathrm{Eu}_{2}\left(\mathrm{C}_{15} \mathrm{H}_{14} \mathrm{NO}_{2}\right)_{3}(\mathrm{OH})_{3} \cdot 3.5 \mathrm{H}_{2} \mathrm{O}$} & I & $30-180$ & 58 & 5.1 & \multirow[t]{4}{*}{$31.4(30.7)$} \\
\hline & II & $180-370$ & 346 & 11.9 & \\
\hline & III & $370-570$ & 410 & 50.4 & \\
\hline & IV & $570-1000$ & 798 & 1.2 & \\
\hline \multirow[t]{4}{*}{$\mathrm{Gd}_{2}\left(\mathrm{C}_{15} \mathrm{H}_{14} \mathrm{NO}_{2}\right)_{3}(\mathrm{OH})_{3} \cdot 3 \mathrm{H}_{2} \mathrm{O}$} & I & $30-130$ & 59 & 4.5 & \multirow[t]{4}{*}{$32.0(32.5)$} \\
\hline & II & $130-380$ & 361 & 13.0 & \\
\hline & III & $380-550$ & 439 & 48.2 & \\
\hline & IV & $550-1000$ & 625 & 2.3 & \\
\hline \multirow[t]{4}{*}{$\mathrm{Tb}_{2}\left(\mathrm{C}_{15} \mathrm{H}_{14} \mathrm{NO}_{2}\right)_{3}(\mathrm{OH})_{3} \cdot 3 \mathrm{H}_{2} \mathrm{O}$} & I & 30-190 & 58 & 4.6 & \multirow[t]{4}{*}{$33.9(33.4)$} \\
\hline & II & $190-380$ & 361 & 11.3 & \\
\hline & III & $380-550$ & 439 & 48.1 & \\
\hline & IV & $550-1000$ & 625 & 2.1 & \\
\hline
\end{tabular}

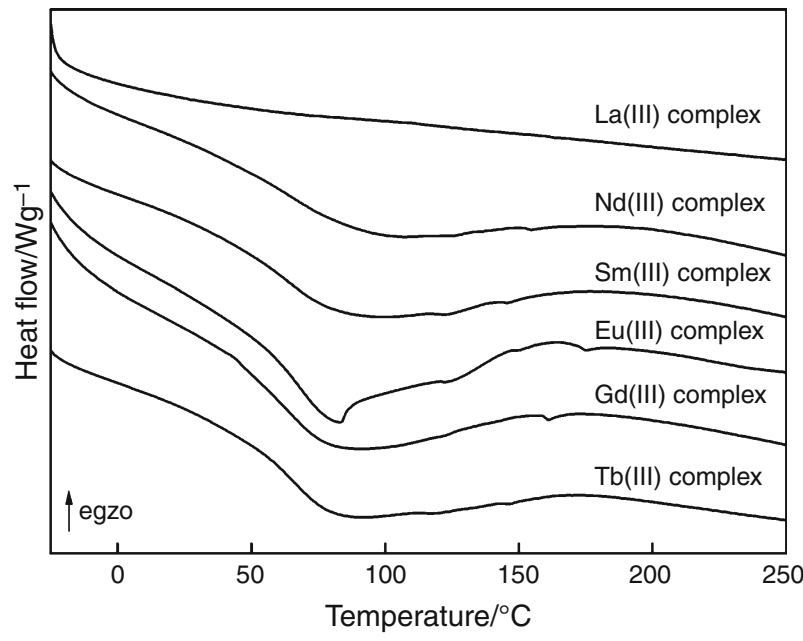

Fig. 6 The DSC curves for dehydration stage obtained for the complexes of $\operatorname{Ln}(\mathrm{III})$ with mefenamic acid

After dehydration step, the resulting anhydrous compounds are stable up to about $350{ }^{\circ} \mathrm{C}$. It is confirmed by plateau observed on $\mathrm{TG}$ curves up to $350{ }^{\circ} \mathrm{C}$. The next decomposition steps for investigated compounds are connected with the degradation of $\mathrm{Ln}-\mathrm{OH}$ bonds and the decomposition of their organic part. Also, the literature studies show that the $\mathrm{OH}$ groups can be released at higher temperatures than the dehydration is observed and this process may be connected with the decomposition of the organic part of the complex [51, 52].

With regard to europium complex, in the first stage of organic part decomposition, the exothermic effect is observed, while the second stage is connected with endothermic peak on DSC curve. For neodymium, samarium, gadolinium and terbium complexes, both stages of organic part decomposition are connected with endothermic peaks on DSC curves. For europium complex, the temperature of maximum mass loss $\left(T_{\max }^{\mathrm{DTG}}\right)$ at first and second stages of organic part degradation is observed at about 350 and $410^{\circ} \mathrm{C}$, whereas for $\mathrm{Nd}, \mathrm{Sm}, \mathrm{Eu}, \mathrm{Gd}$ and $\mathrm{Tb}$ complexes at 360 and $440{ }^{\circ} \mathrm{C}$, respectively. Second stage of organic part decomposition is related to the largest mass loss that for $\mathrm{Eu}(\mathrm{III}), \mathrm{Gd}(\mathrm{III})$ and $\mathrm{Tb}(\mathrm{III})$ complexes achieves about $50 \%$ of initial sample mass. In the case of lanthanum complex, degradation of organic component is connected with two endothermic peaks on DTG curve with $T_{\text {max }}^{\text {DTG }}$ at 400 and $440{ }^{\circ} \mathrm{C}$ and slightly larger mass loss is 
Table 5 Thermoanalytical data for dehydration processes of the complexes of $\operatorname{Ln}(\mathrm{III})$ with mefenamic acid

\begin{tabular}{lllll}
\hline Complex & $\begin{array}{l}\text { Dehydration temperature } \\
\text { range (DSC)/ } /{ }^{\circ} \mathrm{C}\end{array}$ & $\begin{array}{l}\text { Peak temperature } \\
(\mathrm{DSC}) /{ }^{\circ} \mathrm{C}\end{array}$ & $\begin{array}{l}\text { Dehydration } \\
\text { enthalpy/kJ mol }\end{array}$ & $\begin{array}{l}\text { Mass loss/\% } \\
\text { found (calc.) }\end{array}$ \\
\hline $\mathrm{Nd}_{2}\left(\mathrm{C}_{15} \mathrm{H}_{14} \mathrm{NO}_{2}\right)_{3}(\mathrm{OH})_{3} \cdot 2 \mathrm{H}_{2} \mathrm{O}$ & $30-180$ & 95 & 34.5 & $3.5(3.3)$ \\
$\mathrm{Sm}_{2}\left(\mathrm{C}_{15} \mathrm{H}_{14} \mathrm{NO}_{2}\right)_{3}(\mathrm{OH})_{3} \cdot 3 \mathrm{H}_{2} \mathrm{O}$ & $30-190$ & 86 & 51.9 & $4.6(4.8)$ \\
$\mathrm{Eu}_{2}\left(\mathrm{C}_{15} \mathrm{H}_{14} \mathrm{NO}_{2}\right)_{3}(\mathrm{OH})_{3} \cdot 3.5 \mathrm{H}_{2} \mathrm{O}$ & $30-180$ & 83 & 77.8 & $5.1(5.5)$ \\
$\mathrm{Gd}_{2}\left(\mathrm{C}_{15} \mathrm{H}_{14} \mathrm{NO}_{2}\right)_{3}(\mathrm{OH})_{3} \cdot 3 \mathrm{H}_{2} \mathrm{O}$ & $30-130$ & 81 & 49.5 & $4.5(4.7)$ \\
$\mathrm{Tb}_{2}\left(\mathrm{C}_{15} \mathrm{H}_{14} \mathrm{NO}_{2}\right)_{3}(\mathrm{OH})_{3} \cdot 3 \mathrm{H}_{2} \mathrm{O}$ & $30-190$ & 83 & 53.3 & $4.6(4.7)$ \\
\hline
\end{tabular}

observed at the first step of organic part degradation than for the second one.

Small peaks on DTG curves in the temperature range of 500-700 ${ }^{\circ} \mathrm{C}$ are noted for lanthanum, neodymium, samarium, gadolinium and terbium complexes. These peaks are associated with samples mass loss of about $2 \%$ (and $3 \%$ for La complex), what may suggest that the formation of final products of decomposition is preceded by the formation of unstable intermediate product. In case of lanthanide complexes, the formation of unstable oxycarbonates is observed [25, 53].

The solid residues obtained during thermal decomposition of $\mathrm{Sm}$ (III) and $\mathrm{Gd}(\mathrm{III})$ complexes are suitable to metal oxides: $\mathrm{Sm}_{2} \mathrm{O}_{3}$ and $\mathrm{Gd}_{2} \mathrm{O}_{3}$. On the other hand, in case of $\mathrm{La}(\mathrm{III}), \mathrm{Nd}$ (III) $\mathrm{Eu}(\mathrm{III})$ and $\mathrm{Tb}$ (III) compounds, the solid residue masses are higher than expected for metal oxides. It suggests that the decomposition of mentioned complexes in nitrogen atmosphere leads probably to appropriate metal oxide $\left(\mathrm{La}_{2} \mathrm{O}_{3}, \mathrm{Nd}_{2} \mathrm{O}_{3}, \mathrm{Eu}_{2} \mathrm{O}_{3}\right.$ and $\left.\mathrm{Tb}_{4} \mathrm{O}_{7}\right)$ and carbon as final products, what is characteristic for investigations carried out in $\mathrm{N}_{2}$ atmosphere [42].

\section{Evolved gas analysis during thermal decomposition in nitrogen}

FTIR spectra of evolved gas products of the thermal degradation were recorded for $\mathrm{La}(\mathrm{III})$ and $\mathrm{Nd}$ (III) complexes as representatives of the isostructural groups of the investigated compounds. The spectra of gaseous species of decomposition for those complexes were very similar. Stacked plots of FTIR spectra of gaseous species, made for the mefenamic acid complexes with $\mathrm{La}(\mathrm{III})$ and $\mathrm{Nd}(\mathrm{III})$ during their thermal decomposition in nitrogen, are shown in Fig. 7.

On the FTIR spectra of the evolved gases, several characteristic bands can be distinguished. The bands in the wavenumber ranges of 3750-3500 and 1900-1300 $\mathrm{cm}^{-1}$ correspond to vibrations of water molecules. The strong bands in the range of 2400-2300 and 700-600 $\mathrm{cm}^{-1}$ are characteristic vibrations for carbon dioxide, and they correspond to asymmetrical stretching and degenerate
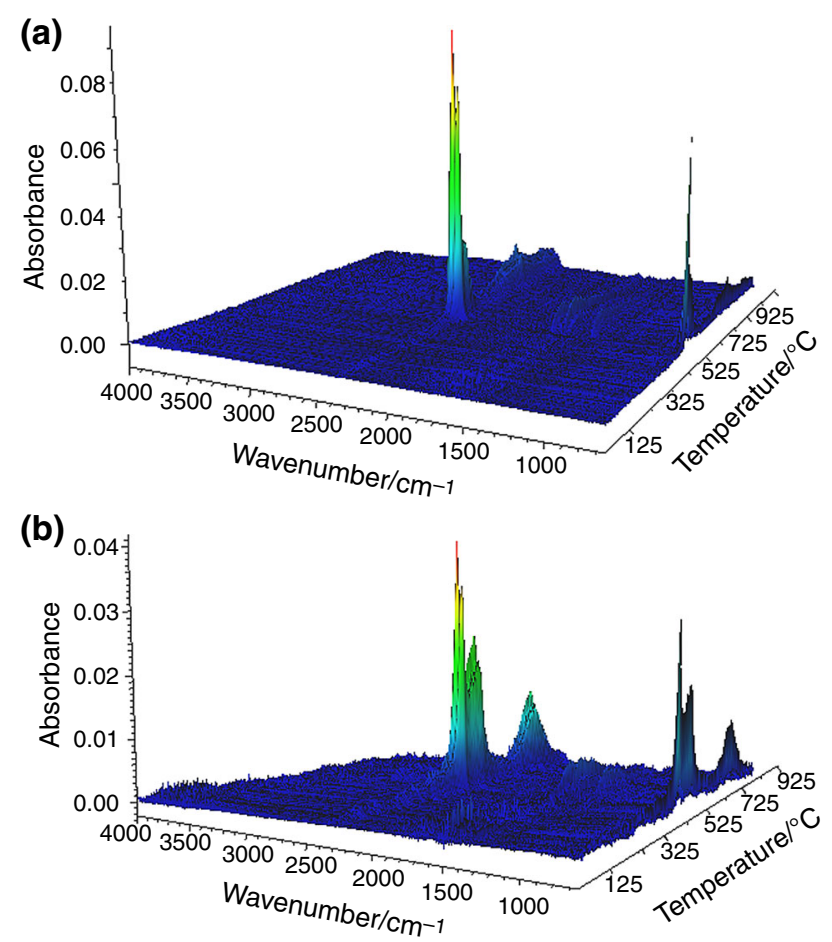

Fig. 7 Stacked plot of the FTIR spectra of the evolved gases for: a La(III) complex, b Nd(III) complex

bending vibrations, respectively. Moreover, the combination of those vibrations can give bands above $3500 \mathrm{~cm}^{-1}$ for $\mathrm{CO}_{2}$ [54]. The presence of hydrocarbon compounds in gaseous products can be also confirmed by the presence of the bands in the range of 3300-2800, 1600-1585, 1500-1400, 1250-1000 and 900-675 $\mathrm{cm}^{-1}$. Taking into account the ligand structure, one may assume that the band above $3000 \mathrm{~cm}^{-1}$ with peak at $3057 \mathrm{~cm}^{-1}$ is due to valence $\mathrm{CH}$ vibrations in aromatic hydrocarbons. The band below $3000 \mathrm{~cm}^{-1}$ with maximum at $2936 \mathrm{~cm}^{-1}$ is associated with the asymmetric and symmetric stretching vibrations of methyl group. Bands at 1590, 1498, 1073 and $743 \mathrm{~cm}^{-1}$ are typical for benzene ring. They correspond to the stretching $\mathrm{CC}$, in-plane $\mathrm{CH}$ bending deformation and out-of-plane $\mathrm{CH}$ bending deformation vibrations, respectively [55]. 
FTIR spectra of gaseous species produced for $\mathrm{La}(\mathrm{III})$ and $\mathrm{Nd}(\mathrm{III})$ complexes during their thermal decomposition in nitrogen in different temperature are presented in Fig. 8.

These spectra confirm that the initial sample heating is connected with the release of water. Two-step process of organic part decomposition is accompanied mainly with the release of carbon dioxide and hydrocarbon compounds. The maximum of carbon dioxide emission is observed at ca. 405 and $372{ }^{\circ} \mathrm{C}$ for $\mathrm{La}(\mathrm{III})$ and $\mathrm{Nd}(\mathrm{III})$ complexes, respectively. The release of $\mathrm{CO}_{2}$ above these temperature values gradually decreases. However, slight increase of the carbon dioxide emission in the temperature value at ca. $600{ }^{\circ} \mathrm{C}$ suggests that the decomposition of intermediate products, possibly oxycarbonates, occurs.
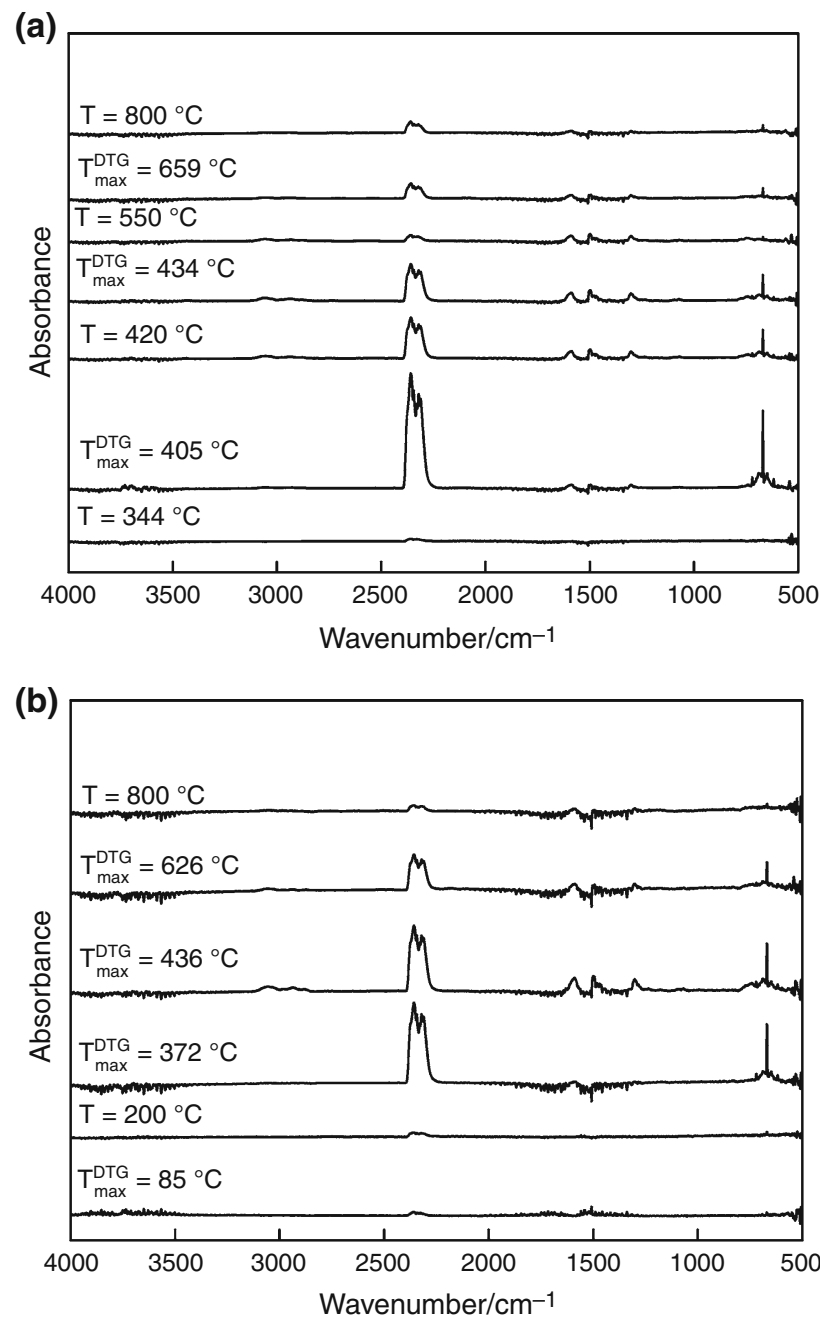

Fig. 8 The FTIR spectra of the evolved gases produced during thermal decomposition in nitrogen atmosphere at different temperatures of a $\mathrm{La}(\mathrm{III})$ complex, b $\mathrm{Nd}(\mathrm{III})$ complex

\section{Conclusions}

In this paper, the study of the synthesis, structure and physicochemical properties of the complexes of mefenamic acid with some lanthanide(III) ions is presented. We have found that in aqueous-methanol solutions and at $\mathrm{pH}$ 6-6.5 $\mathrm{La}$ (III) ions form with mefenamic acid solid complexes having the following formula: $\mathrm{Ln}_{2}\left(\mathrm{C}_{15} \mathrm{H}_{14} \mathrm{NO}_{2}\right)_{3}$ $(\mathrm{OH})_{3} \cdot \mathrm{nH}_{2} \mathrm{O}$, where $\mathrm{Ln}$ is the trivalent cation of lanthanide and $n=2$ for $\mathrm{Nd}(\mathrm{III}), n=3$ for $\mathrm{Sm}(\mathrm{III}), \mathrm{Gd}(\mathrm{III})$ and $\mathrm{Tb}$ (III) as well as $n=4$ for $\mathrm{Eu}(\mathrm{III})$.

The complex with Ln(III) ions has the composition significantly different from the other complexes, and its formula is $\mathrm{La}_{2}\left(\mathrm{C}_{15} \mathrm{H}_{14} \mathrm{NO}_{2}\right)_{5}(\mathrm{OH})$ and does not contain water.

The IR and ${ }^{1} \mathrm{H}$ NMR spectroscopic data for the obtained compounds confirm that the $\mathrm{Ln}$ (III) ions are coordinated to the ligands by the oxygen of the carboxylate group. However, the crystallographic studies are also necessary in order to accurately examine their structures. This is the purpose of the present and further authors' research.

The XRD patterns show that the complex with $\mathrm{La}(\mathrm{III})$ ions has crystalline structure and other analyzed compounds are amorphous.

Thermal studies clearly indicate that thermal decomposition of the investigated compounds in nitrogen atmosphere is four-step process with the exception of the complex with $\mathrm{La}$ (III) ions where the decomposition is a three-step process.

The first step of decomposition of the Nd(III), Sm(III), $\mathrm{Eu}(\mathrm{III}), \mathrm{Gd}(\mathrm{III})$ and $\mathrm{Tb}(\mathrm{III})$ complexes in nitrogen atmosphere is related to dehydration process. For $\mathrm{La}(\mathrm{III}) \mathrm{com}$ plex, no peak on DSC curve is observed in temperature range from -30 to $250{ }^{\circ} \mathrm{C}$, indicating that this compound is anhydrous. On the DSC curves obtained for the other complexes the broad, endothermic peaks are observed; thus, in these compounds one type of water molecules is present. The low values of dehydration enthalpies indicate that these compounds contain only crystallization water. The next decomposition steps for investigated compounds are connected with the degradation of $\mathrm{Ln}-\mathrm{OH}$ bonds and the decomposition of their organic part. The final solid residues are suitable metal oxides or mixture of metal oxides and carbon, what is characteristic for investigations carried out in nitrogen atmosphere.

The TG-FTIR technique provided unreported information concerning the gaseous products that evolved during thermal decomposition in nitrogen atmosphere. The monitoring of the evolved gases during the thermal degradation in dynamic nitrogen atmosphere confirmed that water, carbon dioxide and aromatic hydrocarbons were main products of the decomposition of the obtained complexes. 
Acknowledgements The authors are grateful to Dr Beata MossetyLeszczak from Department of Industrial and Materials Chemistry, Rzeszow University of Technology, for performance of DCS analyses. We thank also Dr Bogdan Myśliwiec for recording NMR spectra and Piotr Szałański for made X-ray analysis in the Laboratory of Spectrometry, Faculty of Chemistry, Rzeszow University of Technology.

Open Access This article is distributed under the terms of the Creative Commons Attribution 4.0 International License (http://crea tivecommons.org/licenses/by/4.0/), which permits unrestricted use, distribution, and reproduction in any medium, provided you give appropriate credit to the original author(s) and the source, provide a link to the Creative Commons license, and indicate if changes were made.

\section{References}

1. Bünzli J-CG. Lanthanides. In: Kirk-Othmer encyclopedia of chemical technology. New York: Wiley; 2013. p. 1-43.

2. Palizban AA, Sadeghi-Aliabadi H, Abdollahpour F. Effect of cerium lanthanide on Hela and MCF-7 cancer cell growth in the presence of transferring. Res Pharm Sci. 2010;5:119-25.

3. Wang K, Li RC, Cheng Y, Zhu B. Lanthanides- the future drugs? Coord Chem Rev. 1999;190:297-308.

4. Song YM, Xu JP, Ding L, Hou Q, Liu JW, Zhu ZL. Syntheses, characterization and biological activities of rare earth metal complexes with curcumin and 1,10-phenanthroline-5,6-dione. J Inorg Biochem. 2009;103:396-400.

5. Zhou J, Wang LF, Wang JY, Tang N. Synthesis, characterization, antioxidative and antitumor activities of solid quercetin rare earth(III) complexes. J Inorg Biochem. 2001;83:41-8.

6. Cunha VR, Izumi CM, Petersen PA, Magalhães A, Temperini ML, Petrilli HM, Constantino VR. Mefenamic acid anti-inflammatory drug: probing its polymorphs by vibrational (IR and Raman) and solid-state NMR spectroscopies. J Phys Chem B. 2014;118:4333-44.

7. Kruszyński R, Trzesowska-Kruszyńska A, Majewski P, Łukaszewicz E, Majewska K, Sierański T, Lewiński B. Structure and properties of the sodium, potassium and calcium salts of 2-(2,3-dimethylphenyl)aminobenzoic acid. J Mol Struc. 2010;970:79-89.

8. Nagabhushanam MV, Prasada Rao ChV, Prabhakar CH. Formulation and evaluation of $\mathrm{hp}-\beta$-cyclodextrin complexes of mefenamic acid tablets. Int J Pharm Technol. 2011;3:2669-79.

9. Kovala-Demertzi D, Hadjipavlou-Litina D, Staninska M, Primikiri A, Kotoglou C, Demertzis MA. Anti-oxidant, in vitro, in vivo anti-inflammatory activity and antiproliferative activity of mefenamic acid and its metal complexes with manganese(II), cobalt(II), nickel(II), copper(II) and zinc(II). J Enzyme Inhib Med Chem. 2009;24:742-52.

10. Woo DH, Han IS, Jung G. Mefenamic acid-induced apoptosis in human liver cancer cell-lines through caspase-3 pathway. Life Sci. 2004;24:2439-49.

11. Kumar N, Chauhan LS, Sharma CS, Dashora N, Bera R. Synthesis, analgesic and anti-inflammatory activities of chalconylincorporated hydrazone derivatives of mefenamic acid. Med Chem Res. 2015. doi:10.1007/s00044-015-1318-8.

12. Almasirad A, Tajik M, Bakhtiari D, Shafiee A, Abdollahi M, Zamani MJ, Khorasani R, Esmaily H. Synthesis and analgesic activity of $\mathrm{N}$-arylhydrazone derivatives of mefenamic acid. J Pharm Pharm Sci. 2005;8:419-25.

13. Kumar N, Chauhan LS. Analgesic and anti-inflammatory potential of hydrazones. J Chem Pharm Res. 2014;6:916-34.
14. Zayed MA, Nassar MI, EL-Gizouli AM. Preparation and characterization of biologically active novel copper ion-pairs of nonsteroidal anti-inflammatory drugs (NSAIDs). J Therm Anal Calorim. 2015;120:959-72.

15. Topacli A, Ide S. Molecular structures of metal complexes with mefenamic acid. J Pharm Biomed Anal. 1999;21:975-82.

16. Andrews PC, Ferrero RL, Junk PC, Kumar I, Luu Q, Nguyen K, Taylor JW. Bismuth(III) complexes derived from non-steroidal anti-inflammatory drugs and their activity against Helicobacter pylori. Dalton Trans. 2010;39:2861-8.

17. Treiber G, Malfertheiner P, Klotz U. Treatment and dosing of Helicobacter pylori infection: when pharmacology meets clinic. Expert Opin Pharmacother. 2007;8:329-50.

18. Sadler PJ, Li H, Sun H. Coordination chemistry of metals in medicine: target sites for bismuth. Coord Chem Rev. 1999;185-186:689-709.

19. Campos FX, Soares MRS, Terezo AJ, Siqueira AB. Synthesis, characterization, and antioxidant evaluation of solid-state mefenamates of some bivalent metals. J Therm Anal Calorim. 2014;115:167-76.

20. Feng J, Du X, Liu H, Sui X, Zhang C, Tang Y, Zhang J. Manganese-mefenamic acid complexes exhibit high lipoxygenase inhibitory activity. Dalton Trans. 2014;43:10930-9.

21. Totta X, Papadopoulou AA, Hatzidimitriou AG, Papadopoulos A, Psomas G. Synthesis, structure and biological activity of nickel (II) complexes with mefenamato and nitrogen-donor ligands. J Inorg Biochem. 2015;145:79-93.

22. Tarushi A, Karaflou Z, Kljun J, Turel I, Psomas G, Papadopoulos AN, Kessissoglou DP. Antioxidant capacity and DNA-interaction studies of zinc complexes with a non-steroidal anti-inflammatory drug, mefenamic acid. J Inorg Biochem. 2013;128:85-96.

23. Dimiza F, Fountoulaki S, Papadopoulos AN, Kontogiorgis CA, Tangoulis V, Raptopoulou CP, Psycharis V, Terzis A, Kessissoglou DP, Psomas G. Non-steroidal antiinflammatory drugcopper(II) complexes: structure and biological perspectives. Dalton Trans. 2011;40:8555-68.

24. Bojarowicz H, Kokot Z, Surdykowski A. Complexes of Fe(III) ions with mefenamic acid. J Pharm Biomed Anal. 1996;15: 339-42.

25. Brzyska W, Ożga W. Preparation and properties of rare earth element complex with mefenamic acid. Polish J Chem. 1993;67:619-25.

26. Brzyska W, Ożga W. Thermal decomposition of yttrium and lanthanide complexes with mephenamic acid. Thermochim Acta. 1992;195:149-55.

27. Müller A, Kögerler P. From simple building blocks to structures with increasing size and complexity. Coord Chem Rev. 1999;182:3-17.

28. Tolman WB, Bino A, Lippard SJ. Self assembly and dioxygen reactivity of an asymmetric, triply bridged diiron(II) complex with imidazole ligands and an open coordination site. J Am Chem Soc. 1989;111:8522-3.

29. Geary WJ. The use of conductivity measurement in organic solvents for characterisation of coordination compounds. Coord Chem Rev. 1971;7:81-122.

30. Cesur S, Gokbel S. Crystallization of mefenamic acid and polymorphs. Cryst Res Technol. 2008;43:720-8.

31. Zheng Z. Ligand-controlled self-assembly of polynuclear lanthanide-oxo/hydroxo complexes: from synthetic serendipity to rational supramolecular design. Chem Commun. 2001;24:2521-9.

32. Chirkst DE, Lobacheva OL, Dzhevaga NV. Ion flotation of lanthanum(III) and holmium(III) from nitrate and nitrate-chloride media. Russ J Inorg Chem. 2012;85:25-8.

33. Rajendiran N, Balasubramanian T. Dual fluorescence of $\mathrm{N}$-phenylanthranilic acid: effect of solvents, $\mathrm{pH}$ and $\beta$-cyclodextrin. Spectrochim Acta A. 2007;68:867-76. 
34. Stalin T, Rajendiran N. Intramolecular charge transfer associated with hydrogen bonding effects on 2-aminobenzoic acid. J Photochem Photobiol A Chemistry. 2006;182:137-50.

35. Sukul NC, Sukul A. High dilution effects: physical and biochemical basis. Dordrecht: Kluwer; 2004.

36. Huang Ch. Rare earth coordination chemistry: fundamentals and applications. Singapore: Wiley; 2010.

37. Pieniążek E, Kalembkiewicz J, Dranka M, Woźnicka E. Syntheses, crystal structures and antioxidant study of $\mathrm{Zn}$ (II) complexes with morin-5'-sulfonic acid (MSA). J Inorg Biochem. 2014;141:180-7.

38. González-Sánchez F. Infra-red spectra of the benzene carboxylic acids. Spectrochim Acta. 1958;12:17-33.

39. Nakamoto K. Infrared and Raman spectra of inorganic and coordination compounds. 4th ed. New York: John Wiley \& Sons; 1986.

40. Bani-Jaber A, Hamdan I, Al-Khalidi B. Sodium mefenamate as a solution for the formulation and dissolution problems of mefenamic acid. Chem Pharm Bull. 2007;55:1136-40.

41. Deacon GB, Phillips RJ. Relationships between the carbon-oxygen stretching frequencies of carboxylato complexes and the type of carboxylate coordination. Coord Chem Rev. 1980;33:227-50.

42. Yan B, Zhang HJ, Zhou GL, Ni JZ. Different thermal decomposition process of lanthanide complexes with N-phenylanthranilic acid in air and nitrogen atmosphere. Chem Pap. 2003;57:83-6.

43. Manhas BS, Trikha AK. Relationship between the direction of shifts in the carbon-oxygen stretching frequencies of carboxylate complexes and the type of carboxylate coordination. J Indian Chem Soc. 1982;59:315-9.

44. Misumi S, Iwasaki N. The Infrared Spectra and Some Properties of Tris-(acetylacetonato) Lanthanide(III) Complexes. Bull Chem Soc Jpn. 1967;40:550-4.

45. Dokorou V, Ciunik Z, Russo U, Kovala-Demertzi D. Synthesis, crystal structures and spectroscopic studies of diorganotin derivatives with mefenamic acid. Crystal and molecular structures of 1,2:3,4-di- $\mu 2-2-[(2,3$-dimethylphenyl)amino]-benzoato-O, O-1,3bis-2-[(-[(2,3-dimethylphenyl)amino]benzoato-O-1,2,4:2,3,4-di$\mu 3$-oxo-tetrakis[di-methyltin(IV)] and 1,2:3,4-di- $\mu 2-2-[(-[(-[(2,3-$ dimethylphenyl)amino]-benzoato-O, O-1,3-bis-2-[(-[(-[(2,3dimethylphenyl)amino]benzoato-O-1,2,4:2,3,4-di- $\mu 3$-oxo-tetrakis [di-n-butyltin(IV)]. J Organomet Chem. 2001;630:205-14.
46. Wang ZL, Niu CJ, Ma JF, Ni JZ. The dehydration behaviour of rare earth complexes of m-nitrobenzoic acid. J Thermal Anal. 1994;41:899-907.

47. Donia AM, Al-Ansi TY, Othman MQ. Synthesis and structural studies of mixed-ligand complexes. J Therm Anal Calorim. 1997;50:857-65.

48. Moreno-Carretero MN, Salas-Peregrín JM, Mata-Arjona A. Thermal studies on metal complexes of 5-nitroso-pyrimidine derivatives. J Therm Anal. 1984;29:553-9.

49. Salas JM, Sanchez E, Valenzuela C. Thermal studies on purine complexes: XV. Thermal behaviour of some new complexes of 8-ethylxanthine and 8-ethyl-3-methylxanthine. Thermochim Acta. 1989;140:13-20.

50. Woźnicka E, Pieniążek E, Zapała L, Byczyński Ł, Trojnar I, Kopacz M. New sulfonic derivatives of quercetin as complexing reagents: synthesis, spectral, and thermal characterization. J Therm Anal Calorim. 2015;120:351-61.

51. Mahé N, Guillou O, Daiguebonne C, Gérault Y, Caneschi A, Sangregorio C, Chane-Ching JY, Car PE, Roisnel T. Polynuclear lanthanide hydroxo complexes: new chemical precursors for coordination polymers. Inorg Chem. 2005;44:7743-50.

52. Khalil MI, Al-Zahem AM, Qunaibit MM. Synthesis, characterization, and antitumor activity of binuclear curcumin-metal(II) hydroxo complexes. Med Chem Res. 2014;23:1683-9.

53. Łyszczek R. Thermal and spectroscopic investigations of new lanthanide complexes with 1,2,4-benzenetricarboxylic acid. J Therm Anal Calorim. 2007;90:533-9.

54. Gerakines PA, Schutte WA, Greenberg JM, van Dishoeck EF. The infrared band strengths of $\mathrm{H}_{2} \mathrm{O}, \mathrm{CO}$ and $\mathrm{CO}_{2}$ in laboratory simulations of astrophysical ice mixtures. Astron Ap. 1995;296:810-8.

55. Silverstein RM, Webster FX, Kiemle DJ. Spectrometric identification of organic compounds. 7th ed. New York: Wiley; 2005. 